Bioeduca: Journal of Biology Education
$\frac{\text { http://iournal.walisongo.ac.id/index.php/bioeduca }}{\text { ISSN 2714-8009 (print), 2715-7490 (online) }}$
Volume 3, Nomor 1, Tahun 2021
Hal. 71-81

\title{
Nilai Konservasi Biodiversitas pada Masyarakat Dayak Kenyah Umo’ Longh Malinau Kalimantan Utara sebagai Etnopedagogi Pembelajaran Biologi
}

\begin{tabular}{|c|c|}
\hline \multicolumn{2}{|c|}{$\begin{array}{c}\text { Findy Riyan Noor Utari }{ }^{1^{*}} \text {, Rusmadi }{ }^{2} \text {, Chusnul Adib Achmad } \\
\text { 1, }{ }^{3} \text { Pendidikan Biologi, Universitas Islam Negeri Walisongo Semarang } \\
{ }^{2} \text { Biologi, Universitas Islam Negeri Walisongo Semarang } \\
{ }^{*} \text { Email: findy.riyan@gmail.com }\end{array}$} \\
\hline Informasi Artikel & ABSTRAK \\
\hline $\begin{array}{l}\text { Submit: } 08-02-2021 \\
\text { Diterima: } 31-03-2021 \\
\text { Dipublikasikan: } 31-03-2021\end{array}$ & $\begin{array}{l}\text { Penelitian ini bertujuan untuk mengidentifikasi nilai kearifan lokal } \\
\text { yang berada pada masyarakat Dayak Kenyah Umo' Longh (Tane' } \\
\text { Olen) yang sesuai dengan kurikulum } 2013 \text { pada konsep } \\
\text { konservasi biodiversitas serta implementasi etnopedagogi yang } \\
\text { digunakan dalam pembelajaran Biologi. Jenis penelitian yang } \\
\text { dilakukan ialah penelitian kualitatif non interaktif atau bisa disebut } \\
\text { penelitian analitis. Penelitian ini dilakukan dengan cara } \\
\text { pengkajian berdasarkan analisis dokumen. Data yang digunakan } \\
\text { dalam penelitian merupakan data sekunder berupa bukti, } \\
\text { catatan, atau laporan historis yang tersusun dalam arsip yang } \\
\text { dipublikasi maupun yang tidak. Teknik pengumpulan data } \\
\text { dengan triangulasi sumber dan triangulasi waktu. hasil penelitian } \\
\text { menunjukan bahwa kearifan lokal masyarakat Dayak Kenyah } \\
\text { Umo' Long memiliki peran yang sangat penting dalam mengelola } \\
\text { alam karena terdapat aturan dalam pembatasan pemanfaatan } \\
\text { Tane' Olen agar seluruh masyarakat dapat memperoleh } \\
\text { manfaatnya secara adil dan berkelanjutan. Konsep konservasi } \\
\text { yang diterapkan dijadikan konten dan bahan ajar dalam } \\
\text { pembelajaran berbasis etnopedagogi yang nantinya akan dapat } \\
\text { meningkatkan literasi konservasi. } \\
\text { Kata kunci: etnopedagogi; kearifan local; tane' olen. }\end{array}$ \\
\hline Penerbit & ABSTRACT \\
\hline $\begin{array}{l}\text { Program Studi Pendidikan } \\
\text { Biologi, Fakultas Sains dan } \\
\text { Teknologi, UIN Walisongo } \\
\text { Semarang }\end{array}$ & $\begin{array}{l}\text { This study aims to identify the value of local wisdom in the Dayak } \\
\text { Kenyah Umo 'Longh (Tane' Olen) community which is related to } \\
\text { the } 2013 \text { curriculum on the concept of biodiversity conservation } \\
\text { and the implementation of ethno pedagogy used in Biology } \\
\text { learning. This type of research is non-interactive qualitative } \\
\text { research or it can be called analytical research. This research } \\
\text { was conducted by an assessment based on document analysis. } \\
\text { The data used in the research is secondary data in the form of } \\
\text { evidence, notes, or historical reports that are arranged in archives } \\
\text { that are published or not. Data collection techniques used } \\
\text { triangulation of sources and triangulation of time. The results } \\
\text { showed that the local wisdom of the Dayak Kenyah Umo 'Long } \\
\text { community has a very important role in managing nature because } \\
\text { there are rules in limiting the use of Tane' Olen so that the whole } \\
\text { community can get its benefits fairly and sustainably. The } \\
\text { conservation concept that is applied is used as content and } \\
\text { teaching material in ethno pedagogy-based learning which will } \\
\text { later be able to increase conservation literacy. } \\
\text { Keywords: ethnopedagogy; local wisdom; tane 'olen. }\end{array}$ \\
\hline
\end{tabular}

Copyright $(02021$, Bioeduca: Journal of Biology Education

Findy Riyan et al. - Nilai Konservasi Biodiversitas pada Masyarakat Dayak Kenyah Umo' Longh Malinau Kalimantan Utara sebagai Etnopedagogi Pembelajaran Biologi 


\section{PENDAHULUAN}

Pewarisan pengetahuan konservasi hutan adat kepada anak-anak sangatlah penting untuk dapat dapat memberikan konsep dan pemanfatan tentang hutan adat, pelestarian serta konservasi lingkungan Penelitian ini bertujuan untuk mengidentifikasi nilai kearifan lokal yang berada pada masyarakat Dayak Kenyah Umo' Longh (Tane' Olen) yang sesuai dengan kurikulum 2013 pada konsep konservasi biodiversitas serta implementasi etnopedagogi yang digunakan dalam pembelajaran. Jenis penelitian yang dilakukan ialah penelitian kualitatif non interaktif atau bisa disebut penelitian analitis. Penelitian ini dilakukan dengan melakukan pengkajian berdasarkan analisis dokumen. Data yang digunakan dalam penelitian merupakan data sekunder berupa bukti, catatan, atau laporan historis yang tersusun dalam arsip yang dipublikasi maupun yang tidak dipublikasikan. Teknik pengumpulan data dengan triangulasi sumber dan triangulasi waktu. Hasil penelitian menunjukan bahwa kearifan lokal masyarakat Dayak Kenyah Umo' Longh memiliki peran yang sangat penting dalam mengelola alam karena terdapat aturan dalam pembatasan pemanfaatan Tane' Olen agar seluruh masyarakat dapat memperoleh manfaatnya secara adil dan berkelanjutan. Konsep konservasi yang diterapkan dijadikan konten dan bahan ajar dalam pembelajaran berbasis etnopedagogi yang nantinya akan dapat meningkatkan literasi konservasi. Penelitian ini hanya terbatas pada upaya konservasi biodiversitas yang dilakukan dan untuk pengembangan lanjutan masih sangat terbuka agar dapat memperluas dan menggali lebih dalam mengenai nilai-nilai kearifan lokal yang ada.

Metode pembelajaran berbasis etnopedagogi dianggap sangat penting dalam mengembangkan proses pembelajaran biologi dikarenakan sudah sangat sesuai dengan kurikulum 2013 bahwa pembelajaran biologi harus dikembangkan dari lingkungan siswa itu sendiri.

Etnopedagogi mencoba untuk menemukan kekuatan yang dapat memotivasi manusia untuk menyadari potensinya, sebuah upaya yang sangat bijak untuk mengurangi kekhawatiran akan hilangnya jati diri, tidak aktifnya kepekaan sosial dan kearifan sosial. Konsep ini diharapkan dapat mengungkap keragaman kearifan lokal (local genius) dan nilai budaya yang terkandung di dalamnya (Alwasilah dkk, 2009).

Dengan adanya pembelajaran Biologi konservasi berbasis etnopedagogi diharapkan nantinya siswa mempunyai kepedulian akan pentingnya dari pendidikan biodiversitas itu. Fenomena alam yang terjadi serta nilai kearifan lokal yang ada didalam masyarakat dayak kenyah ini merupakan sumber pengetahuan yang sangat harus dikembangkan. Dengan mengenali fenomena dan nilai dengan ini diharapkan siswa dapat mengtahui betapa kayanya nilai alam sekitar dan nilai yang diwariskan dari leluhur yang dipunyai oleh bangsa kita sendiri, hingga nantinya siswa akan sadar terhadap sikap kepekaan terhadap lingkungan sekitar.

Mengupayakan ekplorasi nilai-nilai kearifan lokal yang dimiliki oleh masyarakat Dayak Kenyah Umo' Longh dalam upaya pelaksanaan konservasi biodiversitas yang akan ditungangkan kedalam etnopedagogi pembalajaran biologi dan diharapkan nantinya dapat meningkatkan pemahaman para siswa untuk dapat mengerti arti penting dari biodiversitas itu, serta dampak aktivitas manusia terhadap spesies, 
komunitas, dan ekosistem dalam upaya perlindungan dalam penyelamatan biodiversitas, serta dapat belajar tentang konservasi biodiversitas berbasis budaya serta kearifan lokal sekitar.

Perkampungan Dayak Kenyah Umo' Longh yang masih sangat kental dengan kearifan lokal yang diwariskan serta masyarakatnya yang masih dapat mempertahankan kebudayaan nenek moyang mereka, maka penulis mempunyai rasa penasaran tentang bagaimana cara masyarakat kampung Dayak Kenyah Umo' Longh dalam melakukan konservasi biodiversitas yang ada di dalam kampung tersebut serta melihat begitu cepatnya pengurangan keanekaragaman lingkungan di wilayah lain sehingga penurunan biodiversitas yang ada sangat tidak terkontrol (McMillen,2012).

Masyarakat Dayak Kenyah Umo' Longh masih menjaga kelestarian dan konservasi lingkungan yang didalamnya serta terdapat peraturan hutan adat yang masih dipegang teguh oleh masyarakat Dayak Kenyah Umo' Longh. Dalam perkembangannya, masyarakat adat diharap untuk bisa untuk memelihara kebudayaan nenek moyang, serta dapat menjaga lingkungan sekitarnya. Warga didalam suku tersebut dilarang untuk membuka ladang dihutan cadangan. Warga diwajibkan untuk melindungi hutan cadangan agar sumber air tidak rusak. Tetua adat juga melarang warganya untuk mengambil kayu dan tanaman yang berharga dihutan cadangan, namun tetap mengijinkan pemburuan dihutan cadangan dan semua aturan adat tersebut berlaku bagi semua warga suku(Ernawati, 2017).

Dalam perspektif agama sebagai basis etika lingkungan, manusia tidak diperkenankan melakukan tindakan tindakan-tindakan eksploitatif atas alam dan lingkungannya. Tindakan-tindakan ekploitatif itu harus dinilai sebagai tindakan subversif terhadap kemanusiaan itu sendiri. Karena setiap perusakan terhadap alam dan lingkungan pada dasarnya merupakan perusakan terhadap diri sendiri. Tindakaninil yang dijelaskan oleh Alquran: "Telah nampak kerusakan di daratan dan di lautan karena perbuatan manusia, agar Tuhan merasakan pada mereka sebagian dari apa yang telah mereka lakukan, agar mereka kembali (pada ajaran-ajaran-Nya)" (QS. AIRum: 41).

Berdasarkan penjelasan di atas, dapat diketahui bahwa permasalahan yang terjadi yaitu tentang Pewarisan pengetahuan konservasi hutan adat kepada anak-anak sangatlah penting agar dapat memberikan konsep dan pemanfatan, pelestarian serta konservasi di lingkungan hutan adat. Tujuan penelitian ini yaitu untuk mengidentifikasi dari nilai kearifan lokal yang berada di masyarakat Dayak Kenyah Umo' Longh (Tane' Olen) dalam upaya konservasi biodiversitas. Mendeskripsikan hasil dari implementasi etnopedagogi yang digunakan dalam pembelajaran Biologi konservasi.

\section{METODE PENELITIAN}

Jenis penelitian ini adalah kualitatif dengan teknik pengumpulan data yang digunakan dalam penelitian ini ialah penelitian kepustakaan. Teknik tersebut diperoleh dengan cara mempelajari buku, artikel, jurnal, website dan dokumen lain yang berkaitan dengan masalah penelitian, sehingga memperoleh berbagai wawasan serta 
landasan teori, yang dapat digunakan sebagai informasi untuk menganalisis dan mendukung pembahasan masalah penelitian.

Menjaga keabsahan data ini maka peneliti melakukan upaya dalam meningkatkan ketekunan dalam penelitian, triangulasi sumber dan triangulasi waktu. Penelitian kepustakaan meliputi proses identifikasi teoritis sistematis, penemuan kepustakaan dan analisis kepustakaan terdapat informasi yang berkaitan dengan fenomena sosial atau permasalahan penelitian. Teknik analisis data dalam penelitian ini dengan menggunakan model analisis interaktif.

\section{HASIL PENELITIAN DAN PEMBAHASAN}

Kearifan lokal dapat dikatakan sebagai pengetahuan serta kebiasaan yang dapat dikumpulkan atau dipraktikan oleh berbagai masyarakat turun temurun dari generasi ke generasi berikutnya dengan berbagai macam proses didalamnya (Wiati \& Angi, 2015).

Menurut Rusmadi (2016) etika lingkungan adalah bagaimana manusia menilai baik dan buruknya terhadap lingkungan, ada perspektif setiap orang dalam menilai lingkungan. Dalam perkembangan teori terkemuka seperti yang disebutkan Rusmadi ada dua yang menjadi sorotannya yaitu teori Antroposentrisme dan Neoantroposentrisme. Kedua teori ini memiliki perbedaan tentang bagaimana posisi manusia dalam keterkaitannya dengan lingkungan.

Dalam Etika lingkungan, manusia berbicara menyoal bagaimana hubungan yang baik semua kehidupan di bumi. Yaitu antara manusia satu dengan yang lain, manusia dengan makhlukh hidup lain dan seluruh kehidupan di bumi secara keseluruhan. Masyarakat dayak kenyak memiliki keunikan tersendiri dalam hal etika lingkungan mereka memiliki kekhasan tersendiri dalam upaya pelestarian Biodiversitas. Mereka dalam hal mengelola pertanian memiliki budaya tersendiri dalam bentuk mitos-mitos yang dapat dimaknai sebagai penghormatan manusia terhadap keberlanjutan sumber daya alam. Hal ini dapat dilihat dari kepercayaan masyarakat dayak kenyah akan mitos-mitos larangan dalam mengeksploitasi sumber daya alam yang diterima serta dihayati masyarakatnya sebagai bagian dari kearifan lokal Keraf (2002),

Proses pengkajian serta pemanfaatan sumber daya hutan yang mulai dilakukan oleh setiap individu sejak kecil didalam masyarkat uku Kenyah Umo' Longh di desa Setulang, yaitu proses eksternalisasi. Proses peneysuaian ini dilakukan secara berkala dengan waktu yang terus berulang-ulang, maka nantinya akan menghasilan pembiasaan (habitualisasi). Proses obyektivitasakan memberikan tradisi yang akan diwariskan kepada generasi sesudahnya sebagai suatu warisan. Tradisi ini akan mempengaruhi setiap individu di dalam masyarakat suku Dayak Kenyah Umo' Longh ini dan dikenal dengan sebutan internalisasi. Hal ini memberitahu bahwa pengetahuan kearifan lokal masyarakat suku Dayak Kenyah Umo' Longh merupakan produk ciptaan sendiri, dan bukan hanya sekedar warisan dari nenek moyang mereka.

Kearifan Lokal dalam hal pemanfaatan sumber daya alam secara berkelanjutan yang telah dibangun oleh masyarakat Dayak Kenyah seiring dengan kebersinggungan alam dengan masyarakatnya. Kepercayaan dalam menciptakan alam yang 
berkelanjutan bersumber dari mitos mitos dan kepercayaan mereka terhadap Nenek Moyangnya, larangan larangan yang terdiri dari pengelolaan hutan secara berlebihan, aturan dalam memilih lahan, serta dalam bercocok tanam menciptakan keunikan tersendiri dalam hal pengelolaan alam secara bijaksana dan berkelanjutan. Mempercayai alam sebagai tempat roh leluhur bersemayam membuat hubungan manusia dengan alam harmonis. dalam mengelola sumberdaya alam secara baik bahwa hubungan yang baik dengan hutan, sungai, dan makhluk hidup didalamnya akan menciptakan kebaikan, begitupun juga sebaliknya jika manusia menyakiti hutan akan berakibat buruk datang kepadanya (Niman, E. M., 2019).

Kayu Ulin yang ada di hutan oleh masyarakat dayak di gunakan sebagai bahan dalam pembuatan rumah Lamin, rumah Lamin merupakan rumah adat bagi masyarakat dayak dengan bentuk yang memanjang. Rumah ini merupakan rumah yang semi permanen dihuni untuk beberapa generasi, berbentuk memanjang dengan panjang mencapai 300 meter, lebar sekitar 15 meter dan tingginya sekitar 3 meter. Rumah ini adalah rumah yang dihuni secara turun temurun yang mewakili kebudayaan masyarakat. Kontruksi rumah lamin tersebut didasari oleh kayu Ulin dalam kontruksinya dan bahan-bahannya di dominasi oleh kayu Ulin pula. Kayu ulin hanya ada di Kalimantan, kayu yang bahannyasangat kuat, serta tidak muda lapuk. Bila kayu ini terkena air justru akan membuatnya semakin kuat, sehingga tidak salah jika masyarakat menyebutnya kayu besi. Kayu Ulin ini di ambil di hutan untuk skala yang seperlunya dan terbatas, karena kayu ini merupakan kayu yang di hormati, bagi masyarakat Dayak penghormatan kepada kayu Ulin layaknya menghormati leluhur mereka (Rahmawati, 2015).

Pohon yang telah dilestarikan ratusan tahun oleh generasi ke generasi masyarakat dayak, pada sepuluh tahun terakhir ini pemeliharaan keberlangsungannya di serahkan kepada perusahan konsesi hutan. Penjagaan dan pemeliharaan hutan yang ketat tersebut karena masyarakat setempat sangat menghormati pohon ulin, mereka menganggap pohon Ulin adalah pohon yang dikeramatkan tempat roh nenek moyang bertempat tinggal. Dengan demikian pohon Ulin tidak dapat di jual sembarangan di luar desa adat. Dalam proses penebangannya saja melalui tahapan adat yang panjang yaitu melalui proses yang disebut "Mekanyahu" proses ini adalah upacara meminta ijin kepada leluhur penghuni pohon ulin. Begitupun juga ketika melakukan pembukaan lahan yang diperuntukan untuk tujuan pertanian, proses adat akan dilalui sebagai penghormatan terhadap alam dalam (Rahmawati, 2015).

Dalam pertanian masyarakat Dayak mengenal sebuah konsep bercocok tanam yang dikenal sejak dulu di wariskan secara turun temurun yaitu bercocok tanam dengan berpindah-pindah dari ladang satu ke ladan yang lainnya. Konsep ini di lakukan dengan cara bercocok tanam berbagai macam varietas padi tanpa irigasi air, tetapi melalui sistem bertani yang mengikuti siklus tanam sesuai masanya tanpa menggunakan pestisida. Konsep bercocok tanam seperti ini sangat membutuhkan curah hujan yang tinggi sebagai sumber pemenuhan kebutuhan air bagi tanaman. Tampak beberapa petak lahan yang akan dibiarkan karena sengaja untuk tidak 
ditanami setelah beberapa tahun ditanami padi. Hal tersebut dilakukan sebenarnya dengan tujuan agar lahan yang ditidurkan sementara nantinya akan kembali dan siap untuk ditanam kembali sehingga unsur hara permukaan tanah dapat terjaga (Rahmawati, 2015).

Pengelolaan tanah secara tradisional memungkinkan tingkat kerusakan tanah lebih kecil karena pengelolaan tanpa pestisida dan bahan kimia lainnya kedalam tanah berakibat kerusakan tanah lebih kecil. Sistem pertanian masyarakat dayak yang mengembangkan cara bertani subsistem atau pengolahan ladang secara berpindah pindah mengikuti tanah yang lebih subur secara alami yang bergantung pada lahan yang subur karena terdiri dari semak belukar sebuah kesuburan tanah yang alami karena telah di tinggal bertahun tahun. Tanah yang sudah di pakai akan ditinggalkan menuju hutan yang lebih subur dan ladang lama yang telah lama tidak ditanami (Yulianto, 2013).

Pengelolaan hutan yang dimonopoli seperti tanaman industri misalnya kelapa sawit dan pertanian monokultur lainnya sangat bertentangan dengan konsep yang diajarkan oleh leluhur masyarakat Dayak dalam bercocok tanam. Pengelolaan hutan yang mengesampingkan kaidah menjaga kelangsungan sumber daya alam (keanekargaman hayati) dan menjaga kelangsungan lingkungan organik tidak sesuai dengan pemikiran masyarakat dalam mengelola hutan, mereka memiliki perilaku menjaga keberlanjutan lingkungan yang hijau yang diturunkan secara turun temurun yang telah menjadi nafas masyarakat Dayak dalam upaya keberlanjutan konservasi. Kearifan lokal masyarakat tersebut diajarkan secara sederhana dimulai dari pengenalan secara teliti atas berbagai spesies tanaman yang bernilai ekologis, pengelolaan kesuburan tanah merupakan pengetahuan yang telah diturunkan sejak nenek moyang mereka (Rahmawati, 2015).

Dalam hal pengelolaan alam yang hemat energi dan ramah lingkungan tercermin dari Rumah Lamin, rumah lamin yang besar dan panjang diasumsikan sebagai milik bersama, rumah tersebut bisa di huni 25 atau 30 kepala keluarga bahkan sampai 60 kepala keluarga, hal demikian menunjukan bahwa penggunaan pohon sebagai bahan pembuatan rumah sangat di batasi selain itu Perilaku sosial yang merupakan bagian dari ramah lingkungan tercermin dalam kegiatan berladang, ladang dikelola secara bersama oleh keluarga besar dan komunitas sebagai contoh simbol perilaku kolektif masyarakat dayak. Kehidupan saling membantu diantara penghuni rumah besar, jauh dari sifat individualistis, dan kepemilikan privat yang mendominan merupakan bentuk perilaku kolektif tersebut (Rahmawati, 2015).

Dalam hal kepemilikan suatu barang masyarakat Dayak mendasarkan pada keputusan adat dan keluarga besar hal tersebut berakibat pada tidak adanya kompetitif didalamnya. Yang berkembang didalam masyarakat adalah semangat kerja sama membantu dan peduli terhadap warga lainnya, mereka berpegang teguh pada adat dalam memutuskan setiap persoalan yang ada dengan peraturan adat yang mereka sepakati. Kepercayaan dan komitmen yang tinggi masyarkatnya terhadap adat sebagai etika yang mengatur berjalannya kelangsungan hidup baik dalam pengelolaan lahan maupun pemanfaatan hutan didasari pada pemikiran dan sikap yang telah 
diturunkan dari generasi ke generasi bahwa manusia tugasnya adalah menjaga keharmonisan alam melalui kepedulian dan sikap menjaga seluruh alam dan isinya (Rahmawati, 2015).

Vining (2003) mengatakan bahwa perilaku ramah lingkungan didorong oleh keikut sertaan emosi dan ketertarikan terhadap binatang sebagai afeksi yang mendorong sikap serta perilaku sadar terhadap lingkungan. Selain itu dalam kajian lintas budaya yang meneliti tentang hubungan manusia dengan lingkungannya menyatakan bahwa unsur budaya sangat berperan dalm menanamkan kepedulian manusia dengan konservasi serta keberlangsungan sumber daya alam.

Etika lingkungan yang mendasari kehidupan masyarakat Dayak akan kepeduliaannya terhadap keberlangsungan dan sustainability sumberdaya alam tercipta dri kebiasaan orang tua terhadap anaknya untuk memberikan informasi budaya lewat Kebudayaan kebudayaan yang disebut bertutur dari generasi ke generasi sehingga budaya yang mencintai lingkungan tadi dapat tersalurkan kepada anak cucu, karena setiap menuturkan budaya masa lampau masyarakat Dayak menyampaikan informasi yang mempunyai muatan mencintai alam. Hal demikian itulah yang membentuk nilai nilai dan etika kecintaan masyarakat terhadap keberlanjutan sumber daya alam (Kaiser, dkk., 1999).

Menurut Leksono dan Rustaman (2012), dari sistem pembalajaran yang kurang tepat dapat menyebabkan kurangnya pemahaman masyarakat akan pentingnya biodiversitas. Melibatkan langsung peserta didik kedalam pembelajaran konservasi diharapkan nantinya dapat digunakan sebagai sumber belajar, sehingga peserta didik akan dapat berperan secara aktif di dalam kegiatan yang memanfaatkan lingkungan sekitar sehingga dapat meningkatkan kemampuan literasi konservasi didalam pembelajaran Rustaman kurangnya pemahaman masyarakat tentang pentingnya biodiversitas (Erdogan, 2009).

literasi konservasi biodiversitas ialah kemampuan seseorang untuk memahami dan menggunakan pengetahuan konservasi yang dimiliki untuk dapat menyelesaikan masalah biodiversitas, sehingga mempunyai sikap peka terhadap lingkungan yang nantinya dapat digunakan sebagai pertimbangan dalam mengambil keputusan. Menciptakan kesadaran akan pentingnya menjaga biodiversitas kepada peserta didik dapat melalui praktik langsung didalam kehidupan sehari-hari, sehingga pendidikan berbasis lingkungan dapat dilakukan secara lebih optimal (Leksono \& Rustaman, 2012).

Upaya untuk meningkatkan literasi konservasi dengan cara melakukan analisis terhadap konsep yang digunakan untuk mendapatkan materi didalam pembelajaran biologi konservasi. Literasi konservasi ialah kemampuan untuk bisa memahami, mengintegrasikan serta menyelesaikan masalah konservasi yang ada, sehingga dapat meningkatkan sikap kepekaan yang tinggi terhadap diri sendiri serta lingkungan sekitar.

Bahan ajar tentang etnopedagogi yang digunakan untuk dapat meningkatkan literasi konservasi dapat memberikan pemahaman kepada pendidik akan pentingnya biodiversitas serta dampak yang ditimbulkan dari aktivitas manusia di alam terhadap 
spesies, komunitas dan ekosistem. Dalam usaha melindungi biodibersitas itu dilakukan dengan menyasar literasi sebagai tempat menemukan nilai-nilai yang berbasis kearifan lokal, hal demikian yang menciptkaan tercapainya pembangunan yang berkelanjutan. Kearifan lokal yang akan digali sebagai dasar dalam pembelajaran Biologi konservasi berbasis etnopedagogi yang saling terkait dengan kearifan dalam pengelolaan konservasi biodiversitas.

Konsep konservasi yang diterapkan oleh masyarakat Dayak Kenyah Umo' Longh ini dapat dijadikan konten dalam pembelajaran berbasis etnopedagogi yang berkaitan dengan konservasi biodiversitas dan dijelaskan pula konsep konservasi yang diterapkan oleh masyarakat dayak kenyah hal demikian karena kearifan lokal yang ada di tengah-tengah masyarakat menunjukan kepeduliannya terhadap keberlangsungan sumber daya alam, terdapat batasan yang disepakati bersama dalam masyarakat dalam umpaya keberlanjutan biodiversitas tadi.

Materi pembelajar dengan sistem eksplorasi lingkungan sekitar dapat digunakan sebagai pembelajaran sehari-hari siswa karena nantinya dapat menjadi pemecahan masalah lingkungan, karena ilmu yanga diperoleh akan diaplikasikan dalam kehidupan bermasyarakat (Atmojo, 2013). Menurut beberapa pakar pendidikan, materi tertulis belum mampu untuk melibatkan siswanya secara aktif, Oleh karena itu, dibutuhkan metode pembelajaran yang mampu menciptakan lingkungan pembelajaran yang relevan agar siswa dapat berpartisipasi aktif dalam proses pembelajaran. Materi pembelajaran yang menarik dalam penyajian materi merupakan bagian penting dari proses pembelajaran biologi konservasi berbasis etnetnopedagogi.

Pendidikan biodiversitas telah tertera didalam Standar Kompetensi nomor 3 yaitu tentang memahami manfaat dari keanekaragaman hayati, terdiri dari Kompetensi Dasar 3.1. mendeskripsikan tentang konsep keanekaragaman gen, jenis, dan ekosistem melalui kegiatan pengamatan secara langsung serta 3.2. mengomunikasikan tentang keanekaragaman hayati di Indonesia dan usaha pelestarian sumber daya alam. Meskipun sudah menjadi amanat kurikulum, ternyata masih banyak yang kurang literatur yang mengungkapkan tentang pendidikan di sekolah mengenai potensi lokal tentang biodiversitas dan konservasinya, kesiapan sekolah, dan mandat kurikulum terhadap pendidikan biodiversitas dan konservasi itu sendiri. Selama ini pendidikan biodiversitas di Indonesia hampir selalu dikaitkan dengan pendidikan konservasi, sehingga sedikit sekali literatur yang membahas khusus hanya persoalan pendidikan biodiversitas (Setia,2002).

Kurikulum pada pendidikan juga mengikuti kebijakan pemerintah, dimana kurikulum itu sendiri mempunyai aturan pengembangan didalam kompetensi yang meliputi beberapa sikap, pengetahuan, serta keterampilan psikomotorik yang dikemas secara baik didalam berbagai mata pelajaran (Sarah \& Maryono, 2014). Dalam pelaksanaan Kurikulum 2013 sangat memperhatikan berbagai keberagaman, baik dari potensi dan karakteristik daerah, lingkungan, serta nilai-nilai kehidupan. Lebih spesifiknya pada Kompetensi Inti nomer 3 yang terdapat dalam kompetensi Dasar 3.7 yaitu dapat mendeskripsikan keanekaragaman gen, jenis, dan ekosistem melalui 
kegiatan pengamatan; serta 3.8. mendeskripsikan keanekaragaman hayati Indonesia dan usaha pelestarian serta pemanfaatan sumber daya alam (Kemendikbud,2013).

Dengan meningkatkan potensi lokal yang ada tentang tantangan pendidikan keanekaragaman hayati ialah pemanfaatan teknologi di dalam kelas. Dengan bantuan teknologi, kursus keanekaragaman hayati dapat dibawa langsung ke dalam kelas, bahkan pembelajaran jarak jauh, e-book, e-libraries, e-forum, e-journal dapat dilakukan. Namun, nyatanya masih banyak sekolah yang belum memanfaatkan secara maksimal semua potensi teknis untuk mendukung pendidikan keanekaragaman hayati. Seiring dengan perkembangan jaman, baik sarana maupun prasarana, dunia pendidikan dituntut untuk selalu mengikuti tren globalisasi. Sektor pendidikan saat ini perlu mengembangkan sumber belajar efektif yang dapat diakses dimanapun berada. Oleh karenanya, sangat diperlukan media yang tepat agar siswa dapat menggunakanya untuk dapat menambah wawasan. Saat ini pembelajaran tentang pendidikan keanekaragaman hayati hanya terbatas pada siswa di tingkat formal dengan adanya kurikulum yang diberlakukan. Bahkan kewajiban untuk melindungi keanekaragaman hayati Indonesia menjadi kewajiban seluruh rakyat Indonesia. Oleh karena itu, pendidikan keanekaragaman hayati diharapkan dapat diakses oleh semua lapisan masyarakat tanpa terkecuali.

\section{SIMPULAN DAN SARAN}

Kearifan yang terdapat pada masyarakat Dayak Kenyah Umo' Longh memiliki peran yang sangat penting didalam upaya pelaksanaan konservasi biodiversitas, nilai yang berasal dari warisan leluhur sangat kuat jika dibandingkan dengan ketentuan tertulis yang lain. terdapat pegangan hidup yang sangat dipegang teguh yang berbentuk Amanat-Wasiat-Akibat yang digunakan sebagai pengatur didalam segala aspek kegiatan.

Konsep konservasi yang diterapkan oleh masyarakat Dayak Kenyah Umo' Longh ini dapat dijadikan konten dalam pembelajaran berbasis etnopedagogi yang berkaitan dengan konservasi biodiversitas dan dijelaskan pula konsep konservasi yang diterapkan oleh masyarakat dayak kenyah menunjukkan adanya kearifan lokal di dalam memenuhi kebutuhan hidup tanpa merusak lingkungan karena terdapat aturan atau batasan akses dalam pemanfaatan sumber daya yang ada di dalamnya. Bahan ajar etnopedagog digunakan untuk meningkatkan literasi konservasi dan dapat memberikan pemahaman yang lebih mendalam kepada calon pendidik tentang pentingnya biodiversitas serta dampak dari aktivitas manusia terhadap spesies, komunitas dan ekosistem, serta upaya perlindungan biodiversitas yang tujuannya untuk dapat meningkatkan literasi konservasi lingkungan serta mampu mengajarkan konservasi biodiversitas yang berbasis pada budaya serta kearifan lokal setempat sehingga akan tercapai pembangunan yang berkelanjutan.

Penelitian nilai kearifan lokal Masyarakat Dayak Kenyah Umo' Longh ini hanya terbatas pada upaya konservasi biodiversitas yang dilakukan masyarakat setempat. Penelitian lanjutan masih sangat bisa dilakukan untuk dapat memperluas dan 
menggali lebih dalam mengenai nilai-nilai kearifan lokal yang ada pada masyarakat Dayak Kenyah Umo' Longh.

Penelitian lebih lanjut sangat baik dilakukan sehingga dapat dikembangkan proses pembelajaran yang lebih baik lagi kedalam sistem pembelajaran saat ini, contohnya seperti kegiatan praktikum berkelompok sehingga siswa tampak lebih aktif lagi di dalam kegiatan pembelajaran yang sedang berlangsung.

\section{RUJUKAN}

Atmojo, S.E. (2013). "Penerapaan Model Pembelajaran Berbasis Masalah dalam Peningkatan Hasil Belajar Pengelolaan Lingkungan". Jurnal Kependidikan, 43(2), 135-143. https://doi.org/10.21831/jk.v43i2.1968

Erdogan, M. (2009). Components Of Environmental Literacy in Elementary Science Education Curriculum in Bulgaria And Turkey. Eurasia Journal of Mathematics, Science and Teknology Education, 15-26.

https://doi.org/10.12973/ejmste/75253

Ernawati, J. (2017). Tane' Olen Setulang Sebuah tradisi konservasi hutan di Desa Setulang, Malinau, Kalimantan Utara . Pemerintah Desa Wisata Setulang, Malinau, Kalimantan Utara.

Kaiser, F.G., Ranney,M., Hartig,T \& Bowler, P.A. (1999). Ecological behavior, environmental attitude, and feelings of responsibility for the environment. European Psychologist. 4(2), 59-74.

https://psycnet.apa.org/doi/10.1027/1016-9040.4.2.59

Keraf, A. S. (2002). Etika lingkungan. Penerbit Buku Kompas.

Kompetensi Dasar Sekolah Menengah Atas SMA/MA Kurikulum (2013). Jakarta: Pusat Perbukuan Kemendikbud.

Leksono SM. \& Rustaman N. (2012). Pengembangan Literasi Biodiversitas sebagai Tujuan Pembelajaran Biologi Konservasi bagi Calon Guru Biologi. Makalah pada Seminar 392 Nasional dan Rapat Tahunan BKS-PTN B, Bidang IImu MIPA, Fakultas MIPA UNIMED, Medan.

McMillen, H. (2012). Ethnobotanical knowledge transmission and evolution: the case of medicinal markets in Tanga, Tanzania. Economic Botany, 66(2), 121-131.

Niman, E. M. (2019). Kearifan lokal dan upaya pelestarian lingkungan alam. Jurnal Pendidikan dan Kebudayaan MISSIO, 11(1), 91-106.

Rahmawati, H. (2016). Local Wisdom dan Perilaku Ekologis Masyarakat Dayak Benuaq. Indigenous: Jurnal IImiah Psikologi, 13(1).

https://doi.org/10.23917/indigenous.v13i1.2325

Rusmadi, R. (2016). Ecosophy Islam: Studi Tematis-Kontekstual Nilai-Nilai Etika $\begin{array}{lllll}\text { Lingkungan Dalam } & \text { Islam. }\end{array}$ https://doi.org/10.18784/smart.v2i2.391

Sarah, S., \& Maryono. (2014). Keefektivan Pembelajaran Berbasis Potensi Lokal Dalam Pembelajaran Fisika SMA Daklam Meningkatkan Living Values Siswa. Jurnal Pendidikan Sains, 02 (Pendidikan), 36-42. https://doi.org/10.26714/jps.2.1.2014.36-42

Setia, T. M. (2002). Diseminasi Hasilriset Keanekaragaman Hayati Untuk Masyarakat Melalui Program Pendidikan Konservasi [Dissemination of Research Invention in Biodiversity for Community by Conservational Education Programmes ], 6(April), 151- 158. https://doi.org/10.14203/beritabiologi.v6i1.1183

Vining, J. (2003). The connection to other animals and caring for nature. Human Ecology Review, 10 (2). 87-99. https://www.jstor.org/stable/24706957 
Wiati, C. B., \& Angi, E. M. (2015). Studi Konstruksi dan Keberlanjutan Pengetahuan Lokal Dayak Kenyah Oma'Longh di Desa Setulang, Kabupaten Malinau. Jurnal Hutan Tropis, 3(1), 49-60. http://dx.doi.org/10.20527/jht.v3i1.4165

Yulianto, E. H. (2013). Konservasi Tradisional Berbasis Kearifan Lokal Masyarakat Tani Kabupaten Paser (Studi Kasus Desa Semuntai Kecamatan Long Ikis Kabupaten Paser). Agrifor: Jurnal IImu Pertanian dan Kehutanan, 12(2), 140147. https://doi.org/10.31293/af.v12i2.343 